\title{
Impact Assessment of Investment Returns in Indian CPSEs: A Study at Aggregate Level in the Disinvestment Environment
}

\author{
Sudipta Ghosh ${ }^{1}$ \& P. S. Aithal ${ }^{2}$ \\ ${ }^{1}$ Post-Doctoral Fellow, Faculty of Management \& Commerce, \\ Srinivas University, Mangalore, India \\ E-mail: sgcostmanagement@gmail.com \\ ${ }^{2}$ Professor, College of Management \& Commerce, Srinivas University, Mangalore, India \\ OrcidID: 0000-0002-4691-8736; E-mail: psaithal@ gmail.com
}

Area of the Paper: Management.

Type of the Paper: Empirical Study.

Type of Review: Peer Reviewed as per $|\mathrm{C}| \mathrm{O}|\mathrm{P}| \mathrm{E} \mid$ guidance.

Indexed In: OpenAIRE.

DOI: https://doi.org/10.5281/zenodo.5889783

Google Scholar Citation: IJCSBE

\section{How to Cite this Paper:}

Sudipta Ghosh \& Aithal, P. S., (2022). Impact Assessment of Investment Returns in Indian CPSEs: A Study at Aggregate Level in the Disinvestment Environment. International Journal of Case Studies in Business, IT, and Education (IJCSBE), 6(1), 26-37. DOI: https://doi.org/10.5281/zenodo.5889783

International Journal of Case Studies in Business, IT and Education (IJCSBE)

A Refereed International Journal of Srinivas University, India.

Crossref DOI : https://doi.org/10.47992/IJCSBE.2581.6942.0147

(C) With Authors.

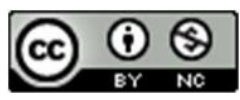

This work is licensed under a Creative Commons Attribution Non-Commercial 4.0 International License subject to proper citation to the publication source of the work.

Disclaimer: The scholarly papers as reviewed and published by the Srinivas Publications (S.P.), India are the views and opinions of their respective authors and are not the views or opinions of the S.P. The S.P. disclaims of any harm or loss caused due to the published content to any party. 


\title{
Impact Assessment of Investment Returns in Indian CPSEs: A Study at Aggregate Level in the Disinvestment Environment
}

\author{
Sudipta Ghosh ${ }^{1}$ \& P. S. Aithal ${ }^{2}$ \\ ${ }^{1}$ Post-Doctoral Fellow, Faculty of Management \& Commerce, \\ Srinivas University, Mangalore, India \\ E-mail: sgcostmanagement@gmail.com \\ ${ }^{2}$ Professor, College of Management \& Commerce, Srinivas University, Mangalore, India \\ OrcidID: 0000-0002-4691-8736; E-mail: psaithal@gmail.com
}

\begin{abstract}
Purpose: The CPSEs were established by the administration of Indian Govt. to serve macroeconomic objectives of our country. They are viewed as a device for growth of the economy with fairness and social justice. Due to unsatisfactory performance of the CPSEs towards fulfillment of the socio-economic objectives of our country, the Govt. of India started the process of disinvestment from the financial year 1991-92 to ensure optimum utilization of national wealth and to augment return on investment of the CPSEs in India. With this background, the current paper is an effort to measure the change (i.e., impact) in investment returns of the CPSEs in the disinvestment environment during the period 2010-11 to 2019-20. Design/Methodology/Approach: Traditional investment ratios are employed for measurement of investment returns of the CPSEs on the basis of secondary data. To capture the impact in investment returns, paired t test is used in the study. Furthermore, the rate of growth related to investment returns are calculated by log linear regression method. Significant difference (if any) in the rate of growth related to different components of aggregate investment returns is measured by Chow statistic.

Findings/Result: Aggregate financial investments have significantly increased. Though the growth rates of selected performance indicators are observed to be significantly positive in majority of the cases, no significant differences in growth rates of the same are found between the two sub-periods (except shareholders' equity). Though significant increase in financial investment is observed during the years under study, impact of investment returns in the disinvestment environment is observed to be negative i.e., it indicates that investment returns (particularly ROCE and ROE) of the CPSEs at aggregate level have decreased significantly during the study period.
\end{abstract}

Originality/Value: In the uninterrupted disinvestment environment, the present study has been conducted to examine the impact of investment returns through ROA, ROCE, and ROE.

Paper Type: Empirical Research.

Keywords: Investment returns, CPSEs, Disinvestment, Impact assessment, ROA, ROCE, ROE.

\section{INTRODUCTION :}

Investment refers to an asset through which the value of money grows over time. Thus, capital generated from investment can be utilized for meeting deficit in income, reimbursement of loans, acquisition of other assets, etc. Thus, investment is the procedure of allocating money to produce returns or profit. In investment, risks as well as return are the two sides of a same coin. Though the objectives of individual investment may differ from one investor to another, the overall objectives of investment are as follows: (1) Preservation of Capital: The main reason of investment by the people is to preserve their capital that has been generated over the years. It helps to keep the hard-earned money safe by investing in appropriate investment instruments. 
(2) Capital Appreciation: This is a common objective where people invest their money in order to ensure that it grows over time. Thus, addition of capital can be achieved by investing money in appropriate financial instruments that offers significant rate of return on the amount invested.

(3) Consistent Income: Investments in appropriate instruments also help a financier to earn consistent income.

(4) Tax Benefits: Investments help the financiers to get tax benefits under various schemes.

(5) Fulfillment of Financial Goals: Investment helps to achieve short-term and long-term financial goals of an enterprise.

In this backdrop, investment return is a relative measure. It measures the profitability of an investment. Investment return helps to assess the effectiveness of different investments at a point of time. It attempts to compute the return of a particular investment with respect to outlay of its investment. In financial management, investment returns are calculated by the following accepted investment ratios. They are: (1) Return on Assets (ROA): ROA measures how much return is generated from its entire resources employed in the industry.

(2) Return on Capital Employed (ROCE): It indicates return with respect to finances of stretched period provided by the proprietor and long-term creditors.

(3) Return on Equity (ROE): It indicates profit that remains with the equity investors.

\section{A BRIEF DESCRIPTION OF INDIAN CPSES :}

The Central Public Sector Enterprises (CPSEs) of India were set up by the administration of Indian Govt. to serve macro-economic objectives in our country. They are viewed as a device for growth of the economy with fairness and social justice. In the beginning, there were5 CPSEs, while there were 348 CPSEs as on 31.03.2019. The CPSEs are considered as tactical players in the construction of an economy. They offer essential commodities in various key sectors of the economy and function in cutthroat markets like information technology. Over the years, due to unsatisfactory performance of the CPSEs towards fulfillment of the socio-economic objectives in the country, the Govt. of India started the process of disinvestment from the financial year 1991-92 in order to ensure optimum utilization of national wealth and to increase productive efficiency of the CPSEs in India.

\section{LITERATURE REVIEW :}

A review of important studies related to public sector enterprises are arranged chronologically and presented below in Table 1:

\begin{tabular}{|c|c|c|}
\hline S. No. & Focus Area & References \\
\hline 1 & $\begin{array}{l}\text { PSEs owned by the State were considered high or low on the } \\
\text { basis of three factors, i.e., in terms of social purpose, } \\
\text { profitability and resource collection. The study observed that } \\
\text { State owned PSEs that work in a competitive market with low } \\
\text { social purpose and low resource collection were the most } \\
\text { appropriate players for disinvestment. }\end{array}$ & 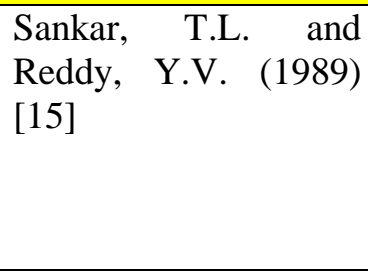 \\
\hline 2 & $\begin{array}{l}\text { The study attempted to evaluate the efficiency of the CPSEs in } \\
\text { Kerala with respect to capacity utilization, profitability, and } \\
\text { productivity. A declining trend was observed in investment } \\
\text { pattern of the CPSEs in Kerala with a low level of capacity } \\
\text { utilization. }\end{array}$ & $\begin{array}{l}\text { Antony, M.T. (1992) } \\
\text { [1] }\end{array}$ \\
\hline 3 & $\begin{array}{l}\text { The Government of India introduced the programme of } \\
\text { disinvestment at the right time when the country faced the } \\
\text { threat of being declared insolvent by the outside economic } \\
\text { society. The study pointed out that the Government of India } \\
\text { failed to achieve the objectives of the disinvestment } \\
\text { programme. }\end{array}$ & $\begin{array}{l}\text { Sankar, T.L. and } \\
\text { Mishra, R.K. (1994) } \\
\text { [14] }\end{array}$ \\
\hline
\end{tabular}




\begin{tabular}{|c|c|c|}
\hline 4 & $\begin{array}{l}\text { The study revealed that profitability performance of } 218 \text { firms } \\
\text { in } 26 \text { different sectors was augmented by } 24 \% \text { points. } \\
\text { Moreover, the study observed that } 57 \% \text { of the profitability was } \\
\text { due to increased productivity. }\end{array}$ & $\begin{array}{llr}\text { LaPorta, } & \text { R. and } \\
\text { Lopez-De, } & \text { S. (1998) } \\
\text { [8] } & \end{array}$ \\
\hline 5 & $\begin{array}{l}\text { The study examined the barriers that existed between the } \\
\text { estimated and the real achievement in the context of various } \\
\text { reform measures that pertained to the process of privatization } \\
\text { in PSEs since } 1991 \text {. }\end{array}$ & Naik, S. D. (2001) [9] \\
\hline 6 & $\begin{array}{l}\text { The study indicated that disinvestment of the PSEs had little } \\
\text { success during the period } 1991 \text { to } 2001 \text {. The researchers } \\
\text { suggested that several criticisms and controversies against } \\
\text { disinvestment could be solved through a translucent procedure. }\end{array}$ & $\begin{array}{l}\text { Ray, K. K. and } \\
\text { Maharana, S. }(2002) \\
\text { [13] }\end{array}$ \\
\hline 7 & $\begin{array}{l}\text { The researcher concluded that the main goal of disinvestment } \\
\text { is to improve the efficiency in the use of labour and wealth of } \\
\text { the country. }\end{array}$ & Patnaik, I. (2006) [11] \\
\hline 8 & $\begin{array}{l}\text { The study results indicated negative effect on the performance } \\
\text { of the firm when both debt and state ownership were used } \\
\text { separately, while their joint influence had a positive impact. }\end{array}$ & $\begin{array}{l}\text { Trien, V. L. and } \\
\text { Jonathan, P.B. (2010) } \\
\text { [17] }\end{array}$ \\
\hline 9 & $\begin{array}{l}\text { The study observed that the CPSEs had generated low } \\
\text { economic returns, low output, huge losses in some cases, and } \\
\text { high cost. Underutilization of installed capacity was the main } \\
\text { reason for unsatisfactory performance in the CPSEs. }\end{array}$ & $\begin{array}{l}\text { Pardeshi, } \text { B. and } \\
\text { Thorat, H. (2014) [10] }\end{array}$ \\
\hline 10 & $\begin{array}{l}\text { The study attempted to contrast the liquidity position in } \\
\text { electricity generation and transmission industries under } \\
\text { CPSEs. The researcher found disappointing liquidity } \\
\text { performance with respect to current ratio for both the } \\
\text { industries. }\end{array}$ & Ghosh, S. (2019) [5] \\
\hline 11 & $\begin{array}{l}\text { The paper analyzed how ERP system affects the monetary } \\
\text { performance of CPSEs under mineral as well as metal sector. } \\
\text { The study found that some ratios performed better which } \\
\text { implied that adoption of ERP system brought positive financial } \\
\text { results in the CPSEs. }\end{array}$ & $\begin{array}{l}\text { Behera, R. K. and } \\
\text { Dhal, S. K. (2020) [2] }\end{array}$ \\
\hline
\end{tabular}

\section{IDENTIFICATION OF RESEARCH GAP :}

From the previous studies as reviewed above, it is observed that many studies were carried out to assess the different aspects of financial performance of the CPSEs during the pre- and post-disinvestment period. However, no studies were found with respect to impact assessment of investment returns of the CPSEs at aggregate level. Hence, the current research may be taken as the first study.

\section{OBJECTIVES :}

To examine the trends in aggregate financial investment.

To examine the growth rates of the different components of aggregate investment returns.

To examine the behaviour of investment returns on the basis of selected ratios.

\section{CONCEPTUAL MODEL AND HYPOTHESES OF THE STUDY :}

\subsection{Conceptual Model for Development of Hypotheses:}

According to the objectives as stated above in section 5, the conceptual model for development of hypotheses has been framed which is shown in figure 1.

6.2: Hypotheses of the Study: Based on the conceptual model as shown above, the hypotheses of the study are stated below:

$\mathbf{1}^{\text {st }}$ Hypothesis $\left(\mathrm{H}_{1}\right)$ :

Null Hypothesis $\left(\mathrm{H}_{01}\right)$ : There is no significant trend in aggregate financial investment.

Alternative Hypothesis $\left(\mathrm{H}_{\mathrm{A} 1}\right): \mathrm{H}_{01}$ is not true. 
$2^{\text {nd }}$ Hypothesis $\left(\mathbf{H}_{2}\right)$ :

Null Hypothesis $\left(\mathrm{H}_{02}\right)$ : There is no noteworthy disparity in growth rates in respect of selected components of aggregate investment returns.

Alternative Hypothesis $\left(\mathrm{H}_{\mathrm{A} 2}\right): \mathrm{H}_{02}$ is not true.

$3^{\text {rd }}$ Hypothesis $\left(\mathrm{H}_{3}\right)$ :

Null Hypothesis $\left(\mathrm{H}_{03}\right)$ : No noteworthy change is observed in the behavior of investment returns.

Alternative Hypothesis $\left(\mathrm{H}_{\mathrm{A} 3}\right): \mathrm{H}_{03}$ is not true.

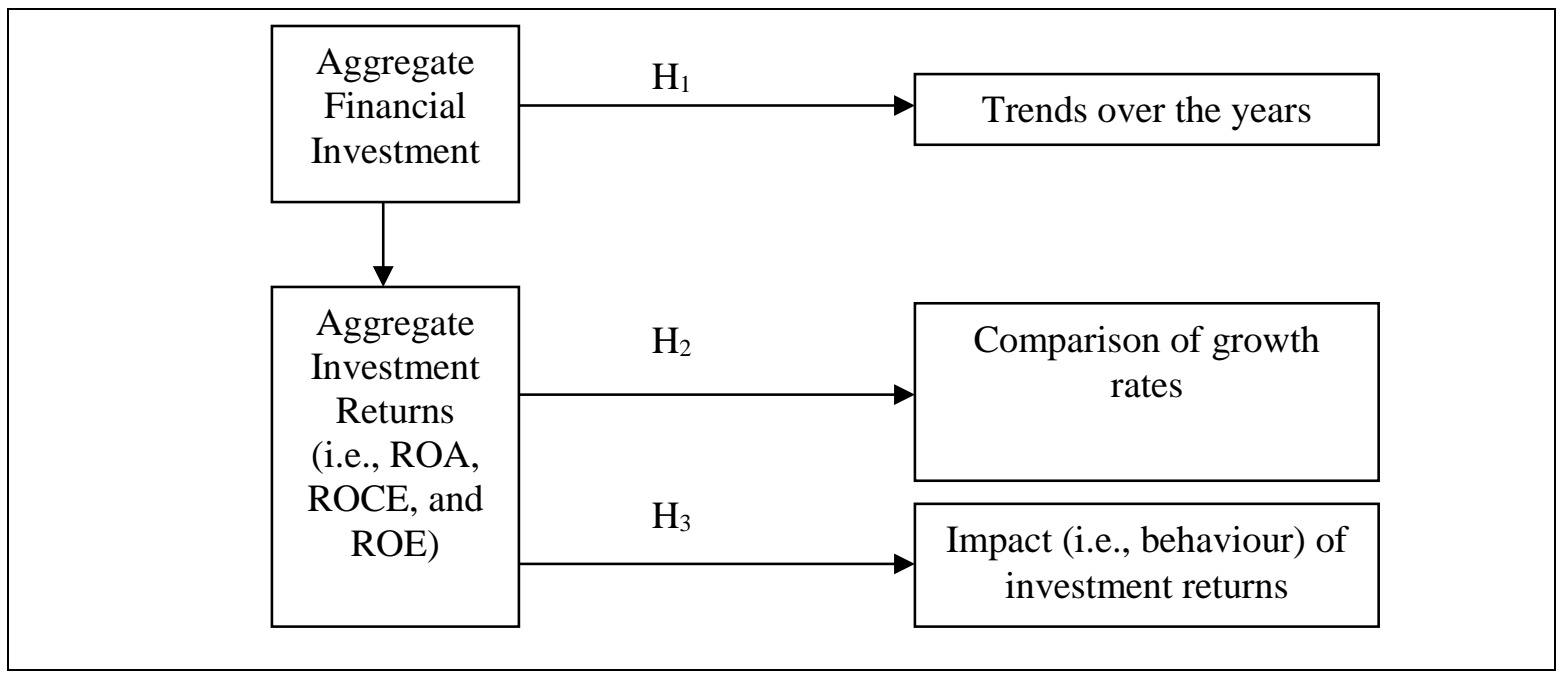

Fig. 1: Conceptual Model for Hypotheses Development

\section{RESEARCH METHODOLOGY :}

7.1 Sample Frame: The sample consists of all the operating CPSESs except departmentally run public enterprises, insurance companies, and banking institutions.

7.2 Study Period: For the study, 10 financial years are selected i.e., from 2010-2011 to 2019-2020.

To gauge the change (i.e., impact) in investment returns, the whole study period (2010-11 to 2019-20) is segmented into two halves (i) $1^{\text {st }}$ half: $2010-11$ to $2014-15$ and (ii) $2^{\text {nd }}$ half: $2015-16$ to $2019-20$.

7.3 Data Source: Resultant statistics are considered in the study. Necessary statistics are collected from the fiscal statements published by Public Enterprises Survey, Government of India. Further, aggregate level statistics have been taken into consideration to reach at a valid conclusion.

7.4 Tools and Techniques: The various tools and techniques that are employed to carry out the study are stated below.

The investment returns will be measured by the ratios which are stated as follows [7]:

ROA $=$ Net Income after Taxes $\div$ Whole Property.

ROCE $=$ Income before Interest and Taxes $\div$ Capital Employed.

ROE $=$ Net Income after Taxes $\div$ Shareholders' Equity.

Trends in aggregate financial investment of the CPSEs in India have been tested by the technique of linear regression equation which is expressed as:

$\mathrm{y}=\mathrm{a}+\mathrm{bt}+\mathrm{e},[4]$

In this respect, $\mathrm{y}=$ aggregate financial investment of the CPSEs; $\mathrm{a}=$ intercept; $\mathrm{b}=$ co-efficient; $\mathrm{t}=$ time; and $\mathrm{e}=$ error term of the linear model.

' $t$ ' test is used to test the significance of ' $b$ '.

Growth rates of various components of aggregate investment returns are measured by "Log Linear Trend" equation which is shown below:

$\log \mathrm{Y}_{\mathrm{t}}=\mathrm{a}+\mathrm{bt}+\mathrm{u}_{\mathrm{t}}[6]$

In this respect, $\mathrm{Y}_{\mathrm{t}}=$ predicted value; $\mathrm{a}=$ intercept; $\mathrm{b}=$ coefficient of the regression equation; $\mathrm{t}=$ time; and $\mathrm{u}_{\mathrm{t}}=$ error term in the regression equation.

' $t$ ' test is applied to find out noteworthy growth (if any) of the different components of aggregate investment returns. 
To judge significant difference in growth rates of the different components of aggregate investment returns between the two halves, Chow statistic is applied which is shown below:

$\mathrm{F}=\left(\mathrm{RSS}_{\mathrm{R}}-\mathrm{RSS}_{\mathrm{UR}}\right) \div \mathrm{k} /\left(\mathrm{RSS}_{\mathrm{UR}}\right) \div\left(\mathrm{n}_{1}+\mathrm{n}_{2}-2 \mathrm{k}\right)[6]$

Where:

$\mathrm{RSS}_{\mathrm{R}}=$ limited remaining total of squares; $\mathrm{RSS}_{\mathrm{UR}}=$ unlimited remaining total of squares; $\mathrm{k}=$ number of parameters expected; $\mathrm{n}_{1}$ and $\mathrm{n}_{2}=$ number of observations; and $\left(\mathrm{n}_{1}+\mathrm{n}_{2}-2 \mathrm{k}\right)=$ degrees of freedom.

To examine the change (if any) in the investment returns of the CPSEs at aggregate level, paired ' $t$ ' statistics is applied which is shown below:

$\mathrm{t}=\overline{\mathrm{d}} \div(\mathrm{s} / \sqrt{\mathrm{n}-1)}[3]$

In this respect, $\overline{\mathrm{d}}$ indicates mean, while ' $\mathrm{s}$ ' indicates standard deviation of the differences $\mathrm{d}_{\mathrm{i}} \mathrm{i} . \mathrm{e} ., \mathrm{d}=($ $\left.\Sigma \mathrm{d}_{\mathrm{i}} \div \mathrm{n}\right)$, and $\mathrm{s}=\sqrt{ } \Sigma \mathrm{d}_{\mathrm{i}}^{2} \div \mathrm{n}-\left(\Sigma \mathrm{d}_{\mathrm{i}} \div \mathrm{n}\right)^{2}$.

The paired ' $\mathrm{t}$ ' test follows $\mathrm{t}$ distribution with $(\mathrm{n}-1)$ degrees of freedom.

To judge the consistency of investment returns at aggregate level, it has been randomly separated into comparatively steady (C.V. $\leq 25 \%)$, moderately fluctuating $(25.1 \% \leq \mathrm{C} . \mathrm{V} . \leq 50.0 \%)$, highly fluctuating $(50.1 \% \leq$ C.V. $\leq 75.0 \%)$, and erratically fluctuating (C.V. $>75.0 \%)[16]$.

\section{EMPIRICAL FINDINGS AND ANALYSIS :}

\subsection{Trends in Aggregate Financial Investment:}

In this section, aggregate financial investment of the CPSEs is analyzed during the entire study period as well as during the two halves of the study. Further, the technique of linear regression model is used to examine statistically the significance of such trend in aggregate financial investment.

Table -2 reveals an increasing trend in aggregate financial investment of the CPSEs during the whole period with a mean value of Rs. $1196647.90 \mathrm{Cr}$. The aggregate financial investment of the CPSEs has fluctuated moderately with C.V. at $37.95 \%$ and it moves between Rs. 666848 Cr. in the year 2010-11 and Rs. 2158877 Cr. in the year 2019-20.

The sub-period analysis shows that aggregate financial investment moves between Rs. $666848 \mathrm{Cr}$. and Rs. 1095554 Cr. in the $1^{\text {st }}$ half, while it ranges between Rs. 1161018 Cr. and Rs. 2158877 Cr. in the $2^{\text {nd }}$ half. Average value with respect to aggregate financial investment has increased from Rs. 865825.80 Cr. in $1^{\text {st }}$ half to Rs. $1527470.00 \mathrm{Cr}$. in $2^{\text {nd }}$ half. C.V. of aggregate financial investment in $1^{\text {st }}$ half is $20.61 \%$ (i.e., relatively stable), while it has fluctuated moderately (C.V. $26.07 \%$ ) in $2^{\text {nd }}$ half.

Concluding Observations: From the above analysis, it is observed that the $2^{\text {nd }}$ half has recorded higher flow of financial investment in comparison to $1^{\text {st }}$ half. Thus, CPSEs have invested significant financial resources in diverse sectors of the nation.

\begin{tabular}{|l|c|}
\hline \multicolumn{2}{|c|}{ Table 2: Aggregate Financial Investment of the CPSEs during 2010-11 to 2019-20 } \\
\hline Year & Aggregate Financial Investment (Rs. in Cr.) \\
\hline $2010-11$ & 666848 \\
\hline $2011-12$ & 729298 \\
\hline $2012-13$ & 845334 \\
\hline $2013-14$ & 992095 \\
\hline $2014-15$ & 1095554 \\
\hline $2015-16$ & 1161018 \\
\hline $2016-17$ & 1245819 \\
\hline $2017-18$ & 1431008 \\
\hline $2018-19$ & 1640628 \\
\hline $2019-20$ & 2158877 \\
\hline Whole Period: & \\
Average & 1196647.90 \\
S.D. & 454141.72 \\
C.V. & $37.95 \%$ \\
\hline $\mathbf{1}^{\text {st }}$ Sub-Period: & \\
Average & 865825.80 \\
S.D. & 178445.28 \\
C.V. & $20.61 \%$ \\
\hline $\mathbf{2}^{\text {nd } \text { Sub-Period: }}$ & \\
\hline
\end{tabular}




\begin{tabular}{|l|c|}
\hline Average & 1527470.00 \\
S.D. & 398245.78 \\
C.V. & $26.07 \%$ \\
\hline
\end{tabular}

1. Whole Period $=2010-11$ to $2019-20 ; 1^{\text {st }}$ Sub-period $=2010-11$ to $2014-15$; and $2^{\text {nd }}$ Subperiod $=2015-16$ to $2019-20$.

2. S.D. $=$ Standard Deviation.

3. C.V. = Coefficient of Variation.

Source: Published Annual Reports of Public Enterprises Survey \& Author's Calculation [12]

Linear regression model is used to examine whether the increasing trend of aggregate financial investment of the CPSEs (as observed in Table - 2) is statistically significant or not. From Table -3 , we found high values of $\mathrm{R}^{2}$ for the two sub-periods and also for the entire study period. These high values of $\mathrm{R}^{2}$ indicate that aggregate financial investment of the CPSEs is well explained by time during the study period.

\begin{tabular}{|l|c|c|c|}
\hline \multicolumn{4}{|c|}{ Table 3: Trend Analysis of Aggregate Financial Investment in CPSEs } \\
during 2010-11 to 2019-20 \\
\hline \multirow{3}{*}{ Particulars } & \multicolumn{3}{|c|}{ Aggregate Financial Investment } \\
\cline { 2 - 4 } & $\mathbf{R}^{\mathbf{2}}$ & Beta Coefficient (b) & t - value \\
\hline $1^{\text {st }}$ Sub-Period & 0.99 & $112020.90^{* * * *}$ & 14.14 \\
\hline $2^{\text {nd }}$ Sub-Period & 0.90 & $239052.70^{* *}$ & 5.22 \\
\hline Whole Period & 0.91 & $142803.50^{* * *}$ & 8.80 \\
\hline \multicolumn{1}{|l}{${ }^{* * * *}$ Noteworthy at 1\% (2-sided). } \\
2. ${ }^{* *}$ Noteworthy at 5\% (2-sided). \\
\hline Source: Author's Calculation.
\end{tabular}

The result of trend analysis (Table -3) of aggregate financial investment of the CPSEs indicates a positive trend in the entire period and found to be noteworthy at $1 \%$. Further, two halves of the study have also shown positive trends which are noteworthy at $5 \%$ and $1 \%$ levels during $1^{\text {st }}$ half and $2^{\text {nd }}$ half respectively.

Statistical Inference: On the whole, trend analysis of aggregate financial investment of the CPSEs have shown significant positive trend (i.e., significant increase in the flow of financial investment) during all the periods. Thus, it results to the rejection of the $1^{\text {st }}$ null hypothesis of our study.

\subsection{Growth Rates of the Selected Components of Aggregate Investment Returns:}

In this section, growth rates have been calculated for the selected components of aggregate investment returns of the CPSEs for all the periods by $\log$ linear trend equation. Furthermore, Chow statistic is used to measure the difference in rate of growth of the selected components of aggregate investment returns of the CPSEs.

Selected components related to aggregate investment returns of the CPSEs in this respect are net profit after taxes, EBIT, total assets, capital employed, and shareholders' equity.

Table -4 reveals high values of $\mathrm{R}^{2}$ for all the selected components of aggregate investment returns of the CPSEs (except net profit after taxes and EBIT in the two sub-periods) for the whole period and also for the two halves of the study. These high values with respect to $\mathrm{R}^{2}$ (Table -4 ) indicate that the selected components of aggregate investment returns are well explained by time during the study period.

EBIT (1.00\%), total assets (1.90\%), capital employed (2.00\%), and shareholders' equity $(1.40 \%)$ have registered positive rates of growth which are noteworthy at $1 \%$ level of significance, while rate of growth related to net profit after taxes $(0.40 \%)$ is found to be insignificant in the whole period.

So far as the analysis of both the halves are concerned, total assets, capital employed, and shareholders' equity have recorded positive rates of growth during both the halves. These results are found to be noteworthy at $1 \%$ level of significance. In the remaining cases, insignificant outcomes are observed.

Statistical Inference: Overall, noteworthy positive rates of growth are observed in majority of the parameters related to performance in the entire period and also in the two halves of the study period. 


\begin{tabular}{|c|c|c|c|c|c|c|}
\hline \multicolumn{7}{|c|}{$\begin{array}{c}\text { Table 4: Growth Rates of the Selected Components of Aggregate Investment Returns } \\
\text { of the CPSEs during 2010-11 to 2019-20 }\end{array}$} \\
\hline \multirow{2}{*}{$\begin{array}{l}\text { Selected } \\
\text { Components of } \\
\text { Aggregate } \\
\text { Investment } \\
\text { Returns } \\
\end{array}$} & \multicolumn{3}{|c|}{ 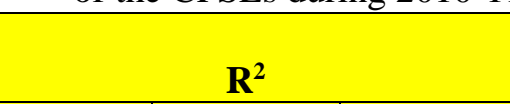 } & \multicolumn{3}{|c|}{ Growth Rates (\%) } \\
\hline & $\begin{array}{l}\text { Entire } \\
\text { Period }\end{array}$ & $\mathbf{1}^{\text {st Half }}$ & $2^{\text {nd }}$ Half & $\begin{array}{l}\text { Entire } \\
\text { Period }\end{array}$ & $1^{\text {st }}$ Half & $2^{\text {nd }}$ Half \\
\hline $\begin{array}{l}\text { Net Profit after } \\
\text { Taxes }\end{array}$ & 0.15 & 0.34 & 0.10 & $\begin{array}{l}0.40^{\mathrm{i}} \\
(1.20)\end{array}$ & $\begin{array}{l}2.20^{\mathrm{i}} \\
(1.25)\end{array}$ & $\begin{array}{l}-1.30^{\mathrm{i}} \\
(-0.56)\end{array}$ \\
\hline $\begin{array}{l}\text { Earnings before } \\
\text { Interest and Taxes } \\
\text { (EBIT) }\end{array}$ & 0.77 & 0.53 & 0.43 & $\begin{array}{l}1.00^{* * * *} \\
(5.22)\end{array}$ & $\begin{array}{l}2.30^{\mathrm{i}} \\
(1.85)\end{array}$ & $\begin{array}{l}2.00^{\mathrm{i}} \\
(1.50)\end{array}$ \\
\hline Total Assets & 0.99 & 0.98 & 0.99 & $\begin{array}{l}1.90^{* * * *} \\
(23.91)\end{array}$ & $\begin{array}{l}4.30^{* * * *} \\
(11.36)\end{array}$ & $\begin{array}{l}4.40^{* * * *} \\
(22.00)\end{array}$ \\
\hline Capital Employed & 0.99 & 0.99 & 0.95 & $\begin{array}{l}2.00^{* * * *} \\
(24.53)\end{array}$ & $\begin{array}{l}4.80^{* * * *} \\
(15.71)\end{array}$ & $\begin{array}{l}3.50^{* * * *} \\
(7.41)\end{array}$ \\
\hline $\begin{array}{l}\text { Shareholders' } \\
\text { Equity }\end{array}$ & 0.95 & 0.96 & 0.99 & $\begin{array}{l}1.40^{* * * *} \\
(12.95)\end{array}$ & $\begin{array}{l}3.70^{* * * *} \\
(8.97)\end{array}$ & $\begin{array}{l}1.50^{* * * *} \\
(15.00)\end{array}$ \\
\hline $\begin{array}{l}\text { 1. Whole Peri } \\
\text { period }=20 \\
\text { 2. }{ }^{* * *} \text { notewort } \\
\text { 3. insignifica } \\
\text { 4. t-values are } \\
\text { 5. Rate of gro }\end{array}$ & $\begin{array}{l}2010-11 \\
6 \text { to } 201 \mathrm{c} \\
1 \%(2-\mathrm{s} \\
\text { cated in } \\
\mathrm{n} \%=\left({ }^{\circ}\right.\end{array}$ & $\begin{array}{l}\text { kets. } \\
100) \text {. }\end{array}$ & & $=2010$ & 201411 & d $2^{\text {nd }} \mathrm{Sub}$ \\
\hline
\end{tabular}

The result of Chow test (Table -5) indicates no noteworthy disparity in the rates of growth between two halves with respect to net income after taxes, EBIT, total assets, and capital employed, while shareholders' equity reveals noteworthy distinction in rates of growth between two halves under study.

\begin{tabular}{|l|c|c|}
\hline \multicolumn{2}{|c|}{$\begin{array}{r}\text { Table 5: Chow Test for Selected Components of Aggregate Investment Returns } \\
\text { of the CPSEs during 2010-11 to 2019-20 }\end{array}$} \\
\hline $\begin{array}{l}\text { Selected Performance } \\
\text { Indicators of Investment } \\
\text { Returns }\end{array}$ & $\begin{array}{c}\text { Calculated Values of } \\
\text { F-Statistic }\end{array}$ & $\begin{array}{c}\text { Differences in Growth Rates } \\
\text { between Two } \\
\text { Sub-Periods }\end{array}$ \\
\hline Net Profit after Taxes & 0.84 & Insignificant \\
\hline $\begin{array}{l}\text { Earnings before Interest and } \\
\text { Taxes (EBIT) }\end{array}$ & 0.33 & Insignificant \\
\hline Total Assets & 2.99 & Insignificant \\
\hline Capital Employed & 3.00 & Insignificant \\
\hline Shareholders' Equity & 6.00 & Significant at 5\% level \\
\hline Source: Author's Calculation. & & \\
\hline
\end{tabular}

Statistical Inference: On the whole, we found no noteworthy disparity in rates of growth between two halves with respect to selected components of aggregate investment returns (except shareholders' equity). This results in the acceptance of the $2^{\text {nd }}$ null hypothesis of our study.

For shareholders' equity, $2^{\text {nd }}$ null hypothesis has been rejected in the study. This implies that growth rate of shareholders' equity $(1.50 \%)$ during $1{ }^{\text {st }}$ half is significantly lower as compared to growth rate of shareholders' equity $(3.70 \%)$ during $2^{\text {nd }}$ half. In this context, it may be stated that retained earnings may not have increased significantly during $2^{\text {nd }}$ half as compared to retained earnings during $1^{\text {st }}$ half. 


\subsection{Aggregate Investment Returns of the CPSEs:}

In this section, aggregate investment returns have been examined with respect to ROA, ROCE, and ROE. After that, paired ' $t$ ' test with respect to selected investment ratios is used to statistically determine the change in the behaviour of investment returns between the two halves chosen in the study.

ROA: Table -6 shows that ROA of the CPSEs has remained almost constant that ranges between 0.02 and 0.04 with a mean value of 0.04 in the entire period. Coefficient of variation in ROA is found to be $25.00 \%$ (i.e., comparatively steady) in the whole period.

Average ROA has slightly decreased from 0.04 in $1^{\text {st }}$ half to 0.03 in $2^{\text {nd }}$ half. ROA ranges between 0.03 and 0.04 during $1^{\text {st }}$ sub-period, while it ranges from 0.02 to 0.04 during $2^{\text {nd }}$ sub-period. ROA is found to be relatively stable (C.V. $25.00 \%)$ in $1^{\text {st }}$ half, while it has fluctuated moderately (C.V. 33.33\%) in $2^{\text {nd }}$ half.

ROCE: ROCE of the CPSEs moves from 0.08 to 0.12 with an average of 0.10 during the whole period. The C.V. of ROCE is comparatively steady (10.00\%) from 2010-11 to 2019-20.

The average value of ROCE has decreased from 0.11 in $1^{\text {st }}$ half to 0.09 in $2^{\text {nd }}$ half. ROCE ranges between 0.09 and 0.12 during $1^{\text {st }}$ half, while the same ranges from 0.08 to 0.09 in the $2^{\text {nd }}$ half. Both halves of the study period show relatively stable performance with respect to ROCE of the CPSEs.

ROE: There is no precise trend in ROE of the CPSEs during the period under study. The ratio moves from 0.07 to 0.14 with a mean of 0.11 and C.V. at $18.18 \%$ (i.e., comparatively steady) in the entire study period.

The average value of ROE $(0.10)$ in $2^{\text {nd }}$ half is lower as compared to the average value of $\operatorname{ROE}(0.13)$ in $1^{\text {st }}$ half. ROE ranges from 0.10 to 0.14 during $1^{\text {st }}$ half, while the same moves from 0.07 to 0.12 during $2^{\text {nd }}$ half. The ROE of the CPSEs is observed to be comparatively steady in both halves of the study.

Concluding Observations: The analyses of investment returns of the CPSEs (in aggregate) indicate positive returns. On the average, aggregate investment returns (i.e., ROA, ROCE, and ROE) of the CPSEs have decreased from $1^{\text {st }}$ half to $2^{\text {nd }}$ half of the study. Furthermore, investment ratios (except ROA in $2^{\text {nd }}$ half) show relatively stable performance. However, consistencies in investment returns are found to be better in $1^{\text {st }}$ half than that of $2^{\text {nd }}$ half.

\begin{tabular}{|l|c|c|c|}
\hline \multicolumn{3}{|c|}{ Table 6: Aggregate Investment Returns of the CPSEs during 2010-11 to 2019-20 } \\
\hline \multirow{2}{*}{ Year } & \multicolumn{3}{|c|}{ Investment Returns (in times) } \\
\cline { 2 - 4 } & ROA & ROCE & ROE \\
\hline $2010-11$ & 0.04 & 0.12 & 0.13 \\
\hline $2011-12$ & 0.04 & 0.12 & 0.13 \\
\hline $2012-13$ & 0.04 & 0.11 & 0.13 \\
\hline $2013-14$ & 0.04 & 0.11 & 0.14 \\
\hline $2014-15$ & 0.03 & 0.09 & 0.10 \\
\hline $2015-16$ & 0.04 & 0.09 & 0.10 \\
\hline $2016-17$ & 0.04 & 0.09 & 0.11 \\
\hline $2017-18$ & 0.03 & 0.09 & 0.11 \\
\hline $2018-19$ & 0.03 & 0.09 & 0.12 \\
\hline $2019-20$ & 0.02 & 0.08 & 0.07 \\
\hline Whole Period: & & & 0.11 \\
Average & 0.04 & 0.10 & 0.02 \\
S.D. & 0.01 & 0.01 & $18.18 \%$ \\
C.V. & $25.00 \%$ & $10.00 \%$ & 0.13 \\
\hline $\mathbf{1}^{\text {st Sub-Period: }}$ & & & 0.02 \\
Average & 0.04 & 0.11 & $15.38 \%$ \\
S.D. & 0.01 & 0.01 & \\
C.V. & $25.00 \%$ & $9.09 \%$ & 0.10 \\
\hline $\mathbf{2}^{\text {nd } \text { Sub-Period: }}$ & & & 0.02 \\
Average & 0.03 & 0.09 & $20.00 \%$ \\
S.D. & 0.01 & 0.01 & \\
C.V. & $33.33 \%$ & $11.11 \%$ & \\
\hline
\end{tabular}


1. Whole Period $=2010-11$ to $2019-20 ; 1^{\text {st }}$ Sub-period $=2010-11$ to $2014-15$; and $2^{\text {nd }}$ Subperiod $=2015-16$ to $2019-20$.

2. $\quad$ S.D. = Standard Deviation.

3. C.V. = Coefficient of Variation.

Source: Author's Calculation.

Paired ' $t$ ' test is employed to examine the impact of investment returns i.e., whether the investment returns of the CPSEs have improved or not. Table -7 reveals that average values of ROA, ROCE, and

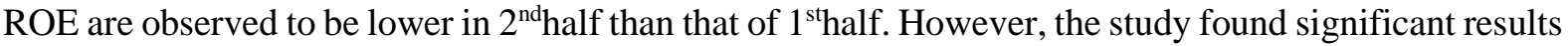
at $1 \%$ for ROCE $(t=5.88)$ and $\operatorname{ROE}(t=9.80)$ as indicated by paired ' $t$ ' test, while the result is found to be insignificant in respect of ROA.

Statistical Inference: In majority of the cases (i.e., ROCE and ROE), investment returns of the CPSEs at aggregate level have decreased significantly (i.e., negative impact) during the study period. Thus, third null hypothesis is rejected for ROCE and ROE. For ROA, the third null hypothesis has been accepted in the study.

\begin{tabular}{|c|c|c|c|}
\hline \multirow[b]{2}{*}{ Particulars } & \multicolumn{3}{|c|}{ Investment Returns (in times) } \\
\hline & ROA & ROCE & ROE \\
\hline Average ( $\left(1^{\text {st }}\right.$ Sub-Period $)$ & 0.04 & 0.11 & 0.13 \\
\hline Average ( $2^{\text {nd }}$ Sub-Period) & 0.03 & 0.09 & 0.10 \\
\hline Calculated value of $\mathrm{t}$ & $2.45^{\mathrm{i}}$ & $5.88^{* * *}$ & $9.80^{* * * *}$ \\
\hline Impact & No Impact & Negative Impact & Negative Impact \\
\hline
\end{tabular}

8.4 Outcome of the Conceptual Model based on accepted Hypotheses:

Based on the accepted hypotheses of the study, the outcome of the conceptual model as stated above in section 6.1 is shown below:

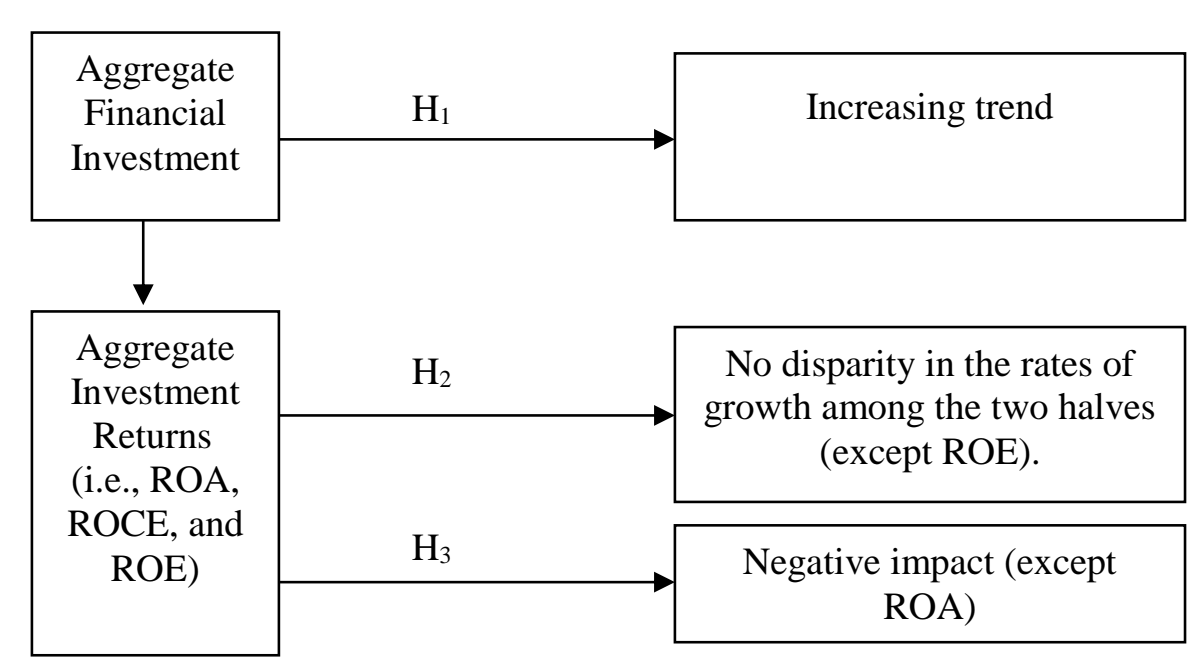

Fig. 2: Outcome of the Conceptual Model based on Accepted Hypotheses of the Study

\section{CONCLUSIONS :}

The aggregate financial investment made by the CPSEs have significantly increased during the whole period with $2^{\text {nd }}$ half showing higher flow of financial investment than that of the $1^{\text {st }}$ half. Though the growth rates of selected performance indicators are found to be significantly positive in most of the cases, no significant differences in growth rates of the same are found among the two halves (except 
shareholders' equity). Lower rate of growth with respect to shareholders' equity in $2^{\text {nd }}$ half as compared to $1^{\text {st }}$ half implies that retained earnings may not have grown significantly during the study period. The average investment returns with respect to ROA, ROCE, and ROE are found to be higher in $1^{\text {st }}$ half that of $2^{\text {nd }}$ half. Though significant increase in aggregate financial investment is observed over the years, the impact of investment returns at aggregate level in the disinvestment environment is observed to be negative i.e., it indicates that investment returns (particularly with respect to ROCE and ROE) of the CPSEs at aggregate level have decreased significantly during the period under study.

\section{SUGGESTIONS :}

(1) Disinvestment has not produced desired results with respect to investment returns generated by the CPSEs, although a change in ownership is not the single solution in this respect. Hence, efforts should be made to improve cost and operational efficiency of the CPSEs. Moreover, industrial structure of the CPSEs should be made more competitive.

(2) To generate higher investment returns of the CPSEs, steps should be taken to ensure best possible utilization of installed capacity.

(3) More emphasis should be given to make the CPSEs efficient in generating returns rather than reducing their ownership.

\section{RESTRICTIONS OF THE STUDY :}

The present study suffers from certain limitations. They are stated below:

(1) The study has been carried out on the basis of resultant statistics.

(2) Though investment ratios are analyzed, other factors like capacity utilization, manpower efficiency, location of enterprise, cost management, management efficiency, etc. that affects the performance of investment returns are not considered in the study.

\section{SCOPE FOR FURTHER RESEARCH :}

In spite of the limitations as stated above, further research work in this field can be carried out which is stated below:

The current research has considered every sector under CPSEs except departmentally run companies, banking companies, and insurance companies. Hence, further research work may be undertaken in those sectors of the CPSEs.

\section{REFERENCES :}

[1] Antony, M.T. (1992). Efficiency in Central Public Sector Enterprises in Kerala: An Analysis of Capacity Utilization, Profitability and Productivity. Ph.D. Thesis. Department of Applied Economics, Cochin University of Science and Technology, 253-262.

Google Scholar $X^{\top}$

[2] Behera, R.K. and Dhal, S.K. (2020). The Impact of ERP Systems on financial Performance of Central Public Sector Enterprises Working in Mineral and Metal Sector. International Journal of Recent Technology and Engineering, 9(2), 144-149.

Google Scholar X

[3] Das, N.G. (1990). Statistical Methods (Vol. II).M.Das \& Co., Kolkata.

[4] Ghosh, R. and Saha, S. (1987). Business Mathematics \& Statistics (Book - I). $5^{\text {th }}$ Edition. New Central Book Agency, Kolkata, 181-182.

[5] Ghosh, S. (2019). Liquidity Performance of Central Power Sector Enterprises in India: A Comparative Study between Power Generation and Power Transmission Industries. PIMT Journal of Research, 12(1), 1-6.

Google Scholar $x^{\top}$

[6] Gujarati, D. N. (2003). Basic Econometrics. $4^{\text {th }}$ Edition, International Edition. Mc Graw-Hill Higher Education, 178-277.

[7] Khan, M.Y. and Jain, P.K. (1994). Financial Management - Text and Problems. $2^{\text {nd }}$ Edition. Tata McGraw-Hill Publishing Company Limited, New Delhi. pp. 103-106. 
[8] LaPorta, R. and Lopez-De, S. (1998). The Benefits of Privatization: Domestic Reform and International Negotiations, World Bank Policy Research, Working Paper, 31795.

[9] Naik, S. D. (2001). Decade of Reforms: Privatization: A Dismal Report Card. Business Line, August 22.

[10] Pardeshi, B. and Thorat, H. (2014). Central Public Sector Enterprises in India: Not for Profit but for Social Profit. International Journal of Research in Engineering, Social Sciences, 4(8), 9-27.

[11] Patnaik,I. (2007). PSU Disinvestment. Available at: http://www.India-seminar.com /2006/557/557\%20ila\%20patnaik.htm, 1-12.

[12] Published Annual Reports of Public Enterprises Survey (2010-11 to 2019-20), Department of Public Enterprises, Government of India, New Delhi.

[13] Ray, K.K. and Maharana, S. (2002). Restructuring PSEs through Disinvestment: Some Critical Issues. Pratibimba, Journal of MIS, 2(2), 56-62.

Google Scholar X

[14] Sankar, T.L. and Mishra, R.K. (1994). Divestments in Public Enterprises: The Indian Experience. International Journal of Public Sector Management, 7(2), 69-88.

Google Scholar $x^{\top}$

[15] Sankar, T.L. and Reddy, Y.V. (1989). Privatization: Diversification of Ownership of Public Enterprises. Institute of Public Enterprise and Booklinks Corporation, Hyderabad, 126-128.

[16] Selvi, A. M. and Vijayakumar, A. (2007). Structure of Profit Rates in Indian Automobile Industries - A Comparison. The Management Accountant, The October Issue, 815-816.

[17] Trien, V.L. and Jonathan, P.B. (2010). Can Two Wrongs Make a Right? State Ownership and Debt in a Transition Economy. Journal of Management Studies,47(7), 1297-1316.

Google Scholar X

$* * * * * * * * * * * * *$ 